\title{
IMPROVEMENT OF CUSTOMERS INCOME THROUGH MURABAHAH PRODUCT IN LKS AL-USWAH DISTRICT CIAMIS
}

\author{
Sumadi \\ Universitas Islam Negeri (UIN) Sunan Gunung Djati, Bandung \\ Email: soemadimoe@gmail.com \\ Frisky Rais Nur Hasan \\ Institut Agama Islam Darussalam (IAID) Ciamis-Jawa Barat \\ Received: 2 Dec 2019 \\ Accepted: 19 Mar 2020
}

\begin{abstract}
This research was conducted to find out the effect of murabahah financing on increasing customer's income. The study was conducted in one of the fastest-growing syariah financial institutions in LKS Al-Uswah Branch Ciamis. Murabahah financing is one of the productive financing developed at LKS Al-Uswah Branch of Ciamis. The descriptive verivikatif method is used with the correlational research approach (correlational research). This study's data collection techniques are by questionnairethe number of samples taken with incidental sampling technique of 30 customers. The data of this research are financial data analyzed with a coefficient of determination and simple linear regression. The paired t-test sample was used to analyze customers' income before and after financing. The magnitude of murabahah financing effect to increase customer income in this research is $17,3 \%$. In comparison, the rest that is $82,7 \%$, is another factor that can influence the growth of customers' income besides murabahah financing. Correlation coefficient value included in the category of moderate level of relations that is equal to 0.416 , the value of correlation is marked positive (+), meaning the relationship of financing with income increase is unidirectional. So it can be concluded that murabahah financing significantly affects the increase in customer's income.
\end{abstract}

\begin{abstract}
Abstrak
Penelitian ini bertujuan untuk mengetahui pengaruh pembiayaan murabahah terhadap peningkatan pendapatan nasabah. Penelitian dilakukan di di LKS Al-Uswah Cabang Ciamis. Pembiayaan murabahah merupakan salah satu pembiayaan produktif yang dikembangkan di LKS Al-Uswah Cabang Ciamis. Metode yang digunakan dalam penelitian ini adalah metode deskriptif verivikatif, dengan pendekatan penelitian korelasional (correlational research). Teknik pengumpulan data menggunakan kuesioner. Jumlah sampel yang diambil dengan teknik incidental sampling sebanyak 30 pelanggan. Data penelitian adalah data keuangan yang dianalisis dengan koefisien determinasi dan regresi linier sederhana. Uji $t$ berpasangan digunakan untuk menganalisis pendapatan nasabah sebelum dan sesudah pembiayaan. Besarnya pengaruh pembiayaan murabahah terhadap peningkatan pendapatan nasabah dalam penelitian ini adalah sebesar $17,3 \%$, sedangkan sisanya sebesar $82,7 \%$ merupakan faktor lain yang dapat mempengaruhi peningkatan pendapatan nasabah selain pembiayaan murabahah. Nilai koefisien korelasi termasuk dalam kategori tingkat hubungan sedang, yaitu sebesar 0,416 , nilai korelasi bertanda positif (+) artinya hubungan pembiayaan dengan peningkatan pendapatan adalah searah. Sehingga dapat disimpulkan bahwa pembiayaan murabahah berpengaruh signifikan terhadap peningkatan pendapatan nasabah.
\end{abstract}

Keywords: Syari'ah Financial Institution, Murabahah Financing, Improvement 


\section{Introduction}

At this time, sharia financial institutions have very significant development. In the last ten years, sharia financial institutions in Indonesia, dominated by banks, experienced significant growth with a 30\% - 40\% growth rate. The difference between sharia financial institutions and conventional financial institutions is in terms of profit. The profits derived from a syariah financial institution should be clear transactions, such as buying and selling get a markup, lease fee, and capital participation (shirkah) to get the results.

The principal business of sharia financial institutions, especially bank financial institutions, is to collect public funds and redistribute the funds to the community through financing based on shariah principles. One form of channeling of funds from sharia financial institutions to customers in the form of funding, namely by murabahah products. Murabahah is one of the products of sharia financial institutions that are currently most popular by the public.

In general, murabahah can be interpreted as trading contract with additional profit (margin) agreed by seller and buyer. The involvement of syariah provision of funds in the business world is very important, because entrepreneurs can overcome the capital problems faced with the productive financing of the shariah financial institutions.

Based on the results of previous research that is Maulidah Kurniawati's research (2013: 80) states that the financing murabahah Bait Al-Mâl wa At-Tamwil (BMT) NU Sejahtera Mangkang Semarang has a positive effect on the business performance of customers, with value $\mathrm{R}$ (correlation coefficient) of 0.690 . While the correlation coefficient is $47.6 \%$. This means that the murabahah financing is able to explain the business performance of customers in Bait Al-Mâl wa At-Tamwil (BMT) of NU Sejahtera Mangkang of $47.6 \%$.

Therefore, to know how big influence financing to customer's income, hence this research conducted at Al-Uswah Financial Institution of Ciamis Branch commonly known as LKS AL-Uswah. The study was conducted considering that the importance of productive financing products from syari'ah financial institutions is useful to increase the business income of its customers, especially in LKS Al-Uswah Ciamis Branch which majority of its customers are traders in Pasar Manis Ciamis.

\section{Theoretical Review}

\section{Sharia Financial Institutions}

Shariah financial institutions are all things concerning syari'ah bank and syari'ah business unit, including institutional, business activities, and ways and processes in conducting its business activities (Syakir, 2013: 1).

The business activities of syari'ah financial institutions consist of three types of products (Syakir, 2013: (1) Liability-based products, such as demand deposits, deposits, and savings. (2) Asset-based products, such as financing. (3) Service-based products, such as remittances, letters of credit, and so forth. The goal of Islamic economics in shari'ah financial institutions is not only focused on the commercial goals reflected in the achievement of maximum profit, but also its role in providing welfare widely for the community. Contribution to participate in realizing the welfare of the community is the role of sharia financial institutions in the implementation of social functions (Umam, 2013: 16). 


\section{Capital in Islamic View}

Capital is goods or equipment that can be used for production process. According to the definition of economy, capital is the goods or products produced yag used to produce the product further. The Islamic economy considers that capital must be free of interest. Islam governs the management of capital in such a way as to be fair, protecting the interests of the poor and the needy by the rule, that capital is not justified to accumulate only the disenfranchised by the rich (Rozalinda: 2014: 114).

Physically according to Rivai (2010: 24-25), there are two types of capital, namely: (1) Fixed capital (fixed capital), ie objects that when benefits are enjoyed does not diminish the existence of substance. Like a machine, a building or a factory. (2) Circulating capital (capital of circulation), such as raw materials and money when benefits are enjoyed, substance lost.

\section{Definition of Financing}

According to Nur Rianto Al-Arif (2012: 146), "financing or financing is funding provided by one party to other parties to support the planned investment, either by themselves or institution". The bank's operational principles consist of fiduciary principle, prudential principle, confidential principle and know your customer principle. These four principles are related to one another (Umam, 2009: 38). For the optimization of productive financing, the application of the principles of management becomes one inevitability.

In order to secure financing objectives and achieve targets, a financing analysis (Umam, 2013: 233) is required. Financing analysis is an important step for the realization of financing. Financing analysis is performed by the account officer of a financial institution as part or committee (team) assigned to analyze the financing application.

\section{Murabahah Financing}

Murabahah is the sale and purchase of goods at the original price with an additional profit agreed (Antonio, 2001: 101). In this case the seller must first notify the cost of goods he bought plus the benefits he wants. According Karim (2004: 88), murabahah derived from the word ribhu (profit) which is a sale and purchase transactions where the bank calls the amount of profit.

Buying and selling is one means of help to help between fellow human beings who are accepted by Allah swt. In the Qur'an it is mentioned "... Allah has justified buying and selling and forbidden usury ..." (Surat al-Baqarah, 2: 275). The verse refers to the halal buying and selling and the prohibition of usury. In this verse, Allah affirms the legality and validity of the sale and purchase in general, and rejects and forbids the concept of ribawi.

Murabahah was initially not related to financing due to murabahah, but in the community of syari'ah murabahah banks emerged as non-ribbon financing alternative in the form of trading contract. Murabahah as applied in sharia banking, is principally based on two main elements, namely the purchase price and related price and agreement on the markup (Rahmawaty, 2007: 192). Murabahah, in practice, the Bank Syari'ah as a provider of goods often do not want to worry with the steps to purchase goods. Therefore, Bank Syari'ah using media "akad wakalah" by giving power to the customer to buy the goods.

\section{Definition of Income}

Income in theoretical economics is the result received, either in the form of money or other for the use of wealth (human services) (Ridwan, 2004: 33). The amount of 
income a person depends on the type of work. Generally, the effect of income on demand is positive in the sense that the increase in income will increase demand (Prianto, 2008: 60).

\section{Methods}

The method used in this research is by descriptive verivikatif method, with correlational research approach (correlational research). So with the method can be known significant relationship between the variables studied. According to Suharsimi Arikunto (2006: 8), "verification research basically wants to test the truth of a hypothesis implemented through data collection in the field". While the correlational research approach aims to detect the extent to which variations in a factor relate to variations on one or more other factors based on the correlation coefficient (Suryabrata, 2004: 82).

Based on the data type, this research is a type of quantitative data. Basically, to see the level of income is menggu feed secondary data sources. However, because the respondents of this study include SMEs (Small and Medium Enterprises), so there are still shortcomings, ie not doing cash flow bookkeeping in financial management. So the data source in this research are: (1) Primary data, obtained directly from murabahah financing clients active in LKS Al-Uswah Branch Ciamis through questionnaire. (2) Secondary data, as supporting data to know murabahah financing obtained by document analysis from LKS Al-Uswah Branch Ciamis.

The research instruments used in this study are as follows: (1) Observations were conducted participatory. (2) Documentation aims to obtain data related to murabahah financing taken from secondary data of LKS Al-Uswah Branch Ciamis. (3) Questionnaire (questionnaire) is used to extract information from respondents regarding the amount of financing, income before, and income after financing.

Validity test is done by measuring aspects based on certain theory, then consulted with experts. The experts were asked his opinion about the questionnaire instruments that have been prepared so that the instrument meets the standards, so the instrument is in accordance with what should be measured in the research (logical validity).

The data analysis in this study are as follows: (1) Descriptive Analysis. Descriptive analysis aims to create a systematic, factual and accurate description of the facts. Descriptive analysis is used to analyze the general description of respondents and general overview of murabahah financing of respondents. (2) Normality Test. Normality test is a test conducted with the aim to assess the distribution of data in a group of data or variables, whether the distribution of data is normally distributed or not. Normality test in this research was done twice test, the first test of normality for different test and secondly normality test for regression analysis. (3) Paired Sample T Test. The purpose of paired sample $t$ test is to compare the effect of the two treatments. Indicator used in this research is the customer's income before and income after murabahah financing. (4) Coefficient of Determination. The coefficient of determination (determinant) is expressed in percent. Coefficient of determination (R2), conducted to know the percentage that contribute to the influence of independent variables simultaneously to the dependent variable. (5) Simple Linear Regression. Regression analysis is a dependency analysis of one or more independent variables on one dependent variable. The regression analysis used in this study predicted one dependent variable based on one independent variable called simple regression analysis. 


\section{Results and Discussion}

This research was conducted at Shari'ah Financial Institution (LKS) Al-Uswah Branch Ciamis, which is located at Jln. Cipto Mangunkusumo No. 44 Ciamis. The AlUswah LKS based in Banjar is one of the fastest growing sharia financial institutions, and the LKS Al-Uswah Branch of Ciamis is one of its branches. LKS Al-Uswah Branch of Ciamis was established and started operation in October 2013.

1. Descriptive Analysis

a. Gender Respondents

The murabahah type of client's finance in the LKS Al-Uswah Branch of Ciamis was taken from 30 respondents, most of whom were $66.7 \%$ of the total were women and the rest were men ie $33.3 \%$ of the total respondents.

\section{b. Age of Respondents}

Age of respondents in this study dominated by age was in the range 32-37 years. This indicates that murabahah financing clients are dominant with productive age ie between 32 and 43 years old, which at that age can work better, eager, have high motivation and easy to adopt new things.

c. Respondents Education Level

Most of the murabahah financing clients of LKS Al-Uswah Branch Ciamis taken as sample of elementary school education / equivalent with the number of 13 people or as much as $43.3 \%$ of the total respondents.

\section{d. Business Type of Respondent}

Most of the murabahah financing clients of LKS Al-Uswah Branch Ciamis taken as respondents, the type of business is trading that is as much as $96.7 \%$ of the total.

e. Number of Respondents Financing

Most of respondents' financing is in the range of Rp1,000,000.00 to $\mathrm{Rp}$ $5,000,000.00$, which is 25 respondents or $83.3 \%$ of the total.

\section{f. Start Murabahah Financing Agreement}

Most of the customers began murabahah financing agreement with LKS Al-Uswah Branch Ciamis has more than 1 year as much as $46.7 \%$ of the total. This indicates that the samples taken from murabahah financing clients are trusted customers.

\section{g. Duration of Murabahah Respondent Financing}

That policy determined LKS Al-Uswah Branch Ciamis that for long repayment murabahah financing of at least 100 days while a maximum of 200 days. Based on research in the field most of the old financing taken murabahah customers is 100 days consisting of 25 people or $83.3 \%$ of the total.

\section{h. Installment of Respondents}

Based on research in the field, most of the respondents per day is between $\mathrm{Rp} 11.000,00$ to $\mathrm{Rp} 48.000,00$ that is $80 \%$ of the total respondents. This indicates that the amount of murabahah financing taken by the respondent is below Rp5.000.000,00, so the installment is no more than Rp50.000,00.

Normality test results based on the above table obtained Sig value. (2-tailed) income before and after earnings of 0.157 and 0.094. That means both Sig values. (2tailed) greater than $0.05(0.157>0.05)$ and (0.094> 0.05), indicating the distribution 
of both data is normally distributed. So with these results indicate that the test paired sample $t$ test feasible to use.

The test results Kolmogorov Smirnov for regression analysis in this study are as follows: Normality test results based on the above table obtained Sig value. (2-tailed) of 0.075. That means the value of Sig. (2-tailed) is greater than 0.05 (0.075> 0.05), indicating the residual value of the data is normally distributed.

\section{Paired Sample T Test}

Based on the date the sig (2-tailed) value is 0.003 smaller than the error rate of $5 \%$ or $\mathrm{a}=0.05(0.003<0.05)$, then $\mathrm{Ha}$ is accepted and Ho is rejected. The significance of this study will compare $\mathrm{t}$ arithmetic with $\mathrm{t}$ table. It is known that the value of $\mathrm{t}$ arithmetic is -3.308 , if the level of significance is 0.05 and uses a two-tailed test, then the critical $t$ value between -2.045 and 2.045. So it can be concluded that the value of $t$ arithmetic smaller than the value of $t$ table $(-3.308<-2.045)$, then Ha accepted and Ho rejected. So it can be concluded that the customer's income after financing murabahah positive impact and increased significantly.

\section{Coefficient of Determination}

The following table shows the value of the correlation coefficient and the value of the coefficient of determination: Model R Square Square Adjusted R Square Std. Error of the Estimate. The table shows the value of correlation coefficient (R) that is equal to 0,416 and the value of coefficient of determination ( $R$ Square) is equal to 0,173 or $17,3 \%$.

\section{Simple Linear Regression}

The results of processing SPSS 20.0 for Windows shows the following table: Model Unstandardized Coefficients Standardized Coefficients T Sig.

Based on the above table it can be concluded that the constant value (a) is 100157,591, while the value of beta is 0,017 . So we can get the following equation: $\mathrm{Y}=$ $100157,592+0,017 \mathrm{X}$.

From the results of the paired sample t test, it can be concluded that the customer's income after financing murabahah positively impacted and increased significantly. It is evident that the sig (2-tailed) value is 0.003 smaller than the error rate of $5 \%$ or a $=$ 0.05 ( $0.003<0.05)$. The value of $t$ arithmetic is -3.308 , if the level of significance 0.05 and using a two-sided test, then ni lai t critical between -2.045 and 2.045. So it can be concluded that the value of $t$ arithmetic is smaller than the value of $t$ table $(-3.308<-$ 2.045).

It is proven that based on the data produced that 20 samples are positive, that means $66.66 \%$ of the samples taken in this study income after financing murabahah increased. While 8 respondents no change, that means $26.67 \%$ of samples taken in this study income did not increase, or in other words its income does not change despite already doing murabahah financing. The remaining 2 samples are negative, that means $6.67 \%$ of the samples taken in this study earnings decreased after financing murabahah.

Results of data processing obtained correlation value of 0.416 . The correlation coefficient is marked positive $(+)$, meaning the relationship of financing with one-way income so that if the financing gets bigger the income is also bigger, and vice versa if the financing decreases the income also decreases. The value also indicates that the correlation value between murabahah (x) and client's (y) is medium level. The value of determination coefficient is known that murabahah financing can explain the variable increase in customer income of $17.3 \%$. It indicates that $82.7 \%$ is another factor that can 
influence variable increase of customer's income which is not explained in this research.

As one of the previous studies by Maulidah Kurniawati (2013: 80) states that the relationship between murabahah financing variables and business performance variables of customers in Bait Al-Mâl wa At-Tamwil (BMT) NU Sejahtera Mangkang Semarang significantly influence the value of R (coefficient correlation) of 0.690 and the coefficient of determination of $47.6 \%$. The result of empirical test in this research is the influence of murabahah financing to the business performance of customer shows the value of $t$ arithmetic 8,422 and $\mathrm{p}$ value (Sig) equal to 0.000 which under alpha $5 \%$. This indicates that murabahah financing affects the business performance of customers.

So with the results of these studies can be concluded that murabahah financing has an important role in helping customers to overcome the problems of capital in business. Therefore, in this study it can not reject the hypothesis that "murabahah financing has a positive effect on the business performance of customers". The statement is proved by the significance test to determine whether the test results are indeed valid to predict from the dependent variable by using $t$ test. This $t$ test serves to test the significance of constants and the dependent variable (income). So by doing this $t$ test can be proven whether murabahah financing can really predict the income of customers in the future.

Hypothesis based on $\mathrm{t}$ test is formulated as follows: Ho = murabahah financing has no significant effect on income. Ha = murabahah financing has a significant effect on revenue. The rules of decision in this t test are as follows: (1) If the value of $t$ arithmetic $>t$ table then Ho is rejected and Ha accepted, meaning significant. (2) If the value of $\mathrm{t}$ arithmetic $<\mathrm{t}$ table then Ho accepted and Ha rejected, meaning not significant.

Based on Table Coefficients can be seen that the value of $t$ arithmetic is 2.424, while the value of $t$ table is known ( $\mathrm{Dk}=\mathrm{N}-2)$ with the error rate of 0.05 is 1.701. That means it can be concluded that the value of $t$ arithmetic $>t$ table $(2.424>1.701)$, then Ho is rejected and Ha accepted which means significant. So in conclusion, murabahah financing affects a significant level of 0.05 to the customer's income. The significance of this is that the research has a truth of $95 \%$ where the possibility of error of $5 \%$.

\section{Conclusion}

Based on the discussion of murabahah financing customer income in LKS AlUswah Branch Ciamis, it can be drawn some conclusions as follows: (1) Most of the murabahah financing of LKS Al-Uswah to its customers is in the range of financing amounting to Rp1,000,000.00 to Rp5,000,000.00. This is because with the amount of financing the requirements that must be met by the customer quite easy because enough with a copy of ID card and photocopy of KK. (2) Murabahah financing has a significant effect on customer's income. The resulting correlation coefficient value is 0.416 with positive sign (+), meaning the relationship of financing with income is unidirectional. The value of determination coefficient is 0.173 , this shows that the independent variable able to explain the dependent variable of $17.3 \%$. Regression equation li simple nier obtained is $\mathrm{Y}=100157,592+0,017 \mathrm{X}$. The result of $\mathrm{t}$ test result can be concluded that $t$ value $>t$ table $(2,242>1,701)$, hence decision of Ho refused and Ha accepted which means murabahah financing significantly influence to customer income. 


\section{REFERENCES}

Al Arif, Nur Rianto. (2012). The Shariah Financial Institution is a practical theoretical study. Bandung: Loyal Library.

Antonio, M. Shafi'i. (2001). Bank Syariah from theory to practice. Jakarta: Gema Insani.

Arikunto, Suharsimi. (2006). The procedure of research is a practical approach. Jakarta: Rineka Cipta.

Karim, Adiwarman. (2004). Islamic Bank: fiqih and financial analysis (second edition). Jakarta: PT RajaGrafindo Persada.

Martono, Nanang. (2014). Social research methods: key concepts. Jakarta: PT RajaGrafindo Persada.

Prianto, Agus. (2008). Microeconomics (a study of theoretical and practical). Malang: SETARA Press.

Rahmawaty, Anita. (2007). Critical review of murabahah products in Syariah Banking in Indonesia. Islamic Economics, 1 (2), 188-203.

Ridwan, Ahmad Hasan. (2004). BMT and Islamic Bank. Bandung: Pustaka Bani Quraisy.

Rivai, Veithzal., Et.al. (2010). Islamic financial management theory, concepts, and applications: practical guidance for financial and business institutions, practitioners, and students. Jakarta: Ghalia Indonesia.

Rozalinda. (2014). Islamic Economics theory and its application on economic activity. Jakarta: PT RajaGrafindo Persada.

Sujarweni, V. Wiratna. (2014). The research methodology is complete, practical and easy to understand. Yogyakarta: PUSTAKABARUPRESS.

Sugiyono. (2014). Quantitative, qualitative and mixed methods. Bandung: Alfabeta.

Suryabrata, Sumadi. (2004). Research methodology. Jakarta: PT RajaGrafindo Persada.

Shakir, Ahmad. (2013). "The role of account officer and the development of financing in Syari'ah Banking." Studia Economica, 1 (1), 1-16.

Umam, Khaerul. (2013). Management of Syariah banking. Bandung: Loyal Library.

Umam, Khotibul. (2009). Islamic economic law "dynamics and developments in Indonesia”. Yogyakarta: Instant Lib. 